\title{
Phylogeography of the Eurasian pine shoot beetle Tomicus piniperda (Coleoptera: Scolytidae)
}

\author{
SARAH RITZEROW*, HEINo KONRAD* and Christian STAUFFER \\ Institute of Forest Entomology, Forest Pathology \& Forest Protection, BOKU, University of Natural Resources \& Applied Life \\ Sciences, 1190 Vienna; Austria; e-mail: stauffer@ento.boku.ac.at
}

Key words. Scolytidae, Tomicus, phylogeography, mtDNA, glacial refugia, nested clade analysis

\begin{abstract}
Tomicus piniperda is a pest in pine stands in Eurasia and is also found in the USA, where it has caused a decline in the abundance of pine since 1992. Knowledge of the genetic structure of pine shoot beetle populations is important for understanding their phylogeographic history and for quarantine control. In this study, European, Asian and American T. piniperda populations were analyzed by sequencing a region of the mitochondrial COI gene. Twenty-five haplotypes (HT) were detected and over $70 \%$ of these HT were found in individual areas, e.g. 5 HT in China, 5 HT in France and 3 HT in Spain. Nested clade analysis revealed that most European and the American population was in a clade containing 9 HT connected by one to two mutational steps. A second clade contained HT from France (2 HT), Spain (2 HT), Sweden (1 HT), Russia (1 HT) and China (5 HT). In this clade, one to 13 mutational steps and 13 missing or theoretical HT were detected. The third clade had 5 HT from France, Russia, Poland, Finland and Switzerland; 1 to 7 mutational steps and 5 missing or theoretical HT were detected. Although only a few significant relationships were found in the nested clade analysis, the following conclusions can be drawn: (1) T. piniperda is a polymorphic species with numerous HT throughout Europe, and HT are likely to exist regarding the missing or theoretical HT; (2) It is likely there were refugial areas in Southern Europe and Western Russia; (3) The Pyrenees formed a barrier to migration after the last ice age; (4) Chinese and European populations have been separated for at least $0.6 \mathrm{MYA}$.
\end{abstract}

\section{INTRODUCTION}

The bark beetle genus Tomicus Latreille 1802 contains six species in Europe and Asia, all of which infest coniferous trees of the genus Pinus. Tomicus piniperda L. and $T$. minor are Eurasian species, T. destruens occurs in the Mediterranean area, and T. brevipilosus, T. puellus and T. pilifer are found only in Asia. The pine shoot beetle $T$. piniperda and the Mediterranean sibling species $T$. destruens are often synonymized (e.g. Schedl, 1932). Recent phylogenetic analyses based on mitochondrial and nuclear DNA, however, reveal that they are two distinct species (Gallego \& Galian, 2001; Kerdelhué et al., 2002; Kohlmayr et al., 2002), thereby confirming the classification of Pfeffer (1994) and Wood \& Bright (1992).

Maturation of callow $T$. piniperda beetles involves feeding within young shoots of Pinus sylvestris, which damages vigorous trees. Adults attack standing pine trees and establish breeding galleries in the bark of weakened trees. The beetles are vectors of blue stain fungi, which help to overcome the resistance of the trees (Solheim et al., 1993). During mass outbreaks, the beetles successfully attack living trees (Postner, 1974). In China, T. piniperda is reported to cause substantial mortality of Pinus yunnanensis (Långström et al., 2002).

Besides P. sylvestris, Pfeffer (1994) listed 16 other species in the genus Pinus as hosts; Wood \& Bright (1992) also mention various Picea species as host trees of $T$. piniperda. Host association is an important factor in the speciation of herbivorous insects such as scolytids (Kelley et al., 2000). Analysis of mitochondrial and nuclear DNA, however, gave no indication of host race formation in $T$. piniperda (Kerdelhué et al., 2002). The genetic structure of scolytids might be influenced by their postglacial history. In Ips typographus (Stauffer et al., 1999) and Ips pini (Cognato et al., 1999), for instance, the genetic structure based on mitochondrial DNA sequences is a consequence of their migration history since the last ice age.

The aim of this study was to reconstruct the post-glacial history of European $T$. piniperda populations. A gap in the geographical distribution of the main host $P$. sylvestris in Europe, between France and Spain - the Pyrenean Range - suggests that gene flow in the associated bark beetle might also be interrupted. Furthermore, divergence between the Asian and European populations may be expected due to the geographic distance. Specimens of the morphologically and ecologically related $T$. minor from European and Asian populations were analyzed for comparison. We used the sequence data from the mitochondrial cytochrome oxidase I (COI) gene and performed a nested clade analysis.

\section{MATERIAL AND METHODS}

\section{DNA sequencing}

Beetles were collected from the bark layer of infested pine trees and kept in absolute ethanol. DNA of single specimens was extracted using the Sigma Genelute Extraction (St. Louis, MO) kit. PCR reactions were carried out in reaction volumes of $50 \mu 1$. A touchdown program was used with an initial annealing temperature of $55^{\circ} \mathrm{C}$, finishing with $47^{\circ} \mathrm{C}$. A 629 bp long fragment, including the partial $3^{\prime}$ end of the COI gene and a non-

\footnotetext{
* Authors contributed equally to the paper.
} 
transcribed region between COI and the tRNA-leu gene, was amplified with the primers C1-J-2441 5'cctacaggaattaaaattttagatgattagc3' and TL2-N-3014 5'tccattgcactaatctgccatatta3' described by Simon et al. (1994). PCR products were purified using the Qiaquick ${ }^{\circledR}$ PCR purification kit (Hilden, Germany) and subsequently sequenced using primer C1-J-2441 and the Big Dye termination reaction kit (Applied Biosystems, Foster City, CA). Sequences were analyzed on an ABI 377 automatic sequencer (Applied Biosystems, Foster City, CA). Each haplotype was sequenced at least twice from independent PCR amplifications in order to avoid PCR artefacts.

\section{Phylogenetic reconstruction}

Sequence alignment was done with Clustal X (Thompson et al., 1997). To infer phylogenetic relationships, maximum parsimony analysis was performed with the software package PAUP* 4.0b3 (Swofford, 1998). Support for the nodes was calculated with bootstrap replicates using maximum parsimony (1000 steps) and neighbour joining (1000 steps) search methodologies.

\section{Nested clade analysis}

We evaluated the data with an unrooted network using a statistical parsimony (SP) criterion (Templeton et al., 1992). The SP network was constructed with the computer program TCS version 1.13 (Clement et al., 2000). To infer population histories, nested clade analysis (Templeton et al., 1995) was carried out. The nesting design was constructed on the SP network following the rules in Crandall (1996) and Templeton (1998). After transforming the network into a nested series of clades (Templeton et al., 1987; Templeton \& Sing, 1993), association between these clades and geographic distances were tested using the permutational contingency analysis in the program GeoDis 2.0 (Posada et al., 2000). Appendix I of Templeton (1998) was used to interpret the results.

\section{RESULTS AND DISCUSSIONS}

For the phylogeographic analysis, $74 \mathrm{~T}$. piniperda specimens were sequenced. All sequences collected for this study were deposited in Genbank and accession numbers are listed in Table 1. Twenty-five haplotypes (HT) were detected; sequence divergence was between $0.18 \%$ and $2.48 \%$. All substitutions were transitions and on the $1^{\text {st }}$ or $3^{\text {rd }}$ codon positions. Eighteen HT $(72 \%)$ were found only in individual areas, such as China (5 HT), France (5 HT), Spain (3 HT), Russia (2 HT), Austria (2 HT) and Sweden (1 HT).

Because maximum parsimony methods (MP) do not necessarily reflect population history and may indeed be misleading for shallow genealogies (Posada \& Crandall, 2001), a nested clade analysis was performed. The MP analysis is not presented because it showed too little resolution. The nested clade design included the $25 \mathrm{HT}$ across three nesting levels (Fig. 1). Most Central European and the American population were in clade 3-1 containing 9 HT, which were separated by one or two mutations. Only one missing or theoretical HT was detected. Clade 3-2 contained HT found in individual countries: France (2), Spain (2), Sweden (1), Russia (1) and China (5). One to 13 mutational steps were detected and the calculations indicated 13 missing or theoretical HT. The Russian HT XX was 4 steps apart from the Chinese HT and 6 steps apart from the European HT XVIII. The Spanish HT
XVII was 7 steps apart from the Swedish HT X. Clade 3-3 had 5 HT from France, Spain, Russia, Poland, Finland and Switzerland. Here, 1 to 7 mutational steps and 5 missing or theoretical HT were detected. Four clades (1-1, 3-1, 3-2 and total cladogram) revealed significant associations between geographic and genetic variation (Table 2). No inference on population history could be made on clade 1-1 because values for clade distance (Dc) and nested clade distance (Dn) were not significant (Templeton, 1998). The values for clade 3-2 containing populations from Europe and Asia could not distinguish between fragmentation and isolation by distance. This is congruent with the hypothesis (see below) of fragmentation of the European population during the glacial period and the obvious geographical isolation of the Asian populations. As a result of the ambiguities in the cladogram there were no tip clades in the total cladogram. The nested clade analysis revealed that more sampling will be needed to fully resolve the population history of $T$. piniperda. It is likely that many more HT will be detected. This is also indicated by the 18 missing or theoretical HT detected in the nested clade analysis.

$T$. piniperda can be considered as a highly polymorphic species because other European scolytid species have fewer HT (Stauffer, 2003). This polymorphism may be due to the existence of several distinct refugial areas during the last ice age. A prolonged genetic isolation in the refugial areas could have led to the selection of different HT. The data presented here provide little information about the origins of most HT and their migration routes when the temperature increased after the last ice age. Our data suggest the area of Southern France, the Iberian Peninsula and the area south of St. Petersburg, Russia, served as possible refugial areas. The HT found there were not detected elsewhere. Moreover, they showed a high sequence divergence. Four main refugial areas were proposed for the main host, P. sylvestris, according to pollen findings: (1) Iberian Peninsula, (2) South France, (3) Balkan Mountains, (4) the area north of Moscow (Huntley \& Birks, 1983). We did not incorporate data from the Balkan Mountains, but for other areas it is suggested there is a parallel evolution of $T$. piniperda and its host $P$. sylvestris.

The Pyrenees apparently formed a migratory barrier after the temperature increased. Assuming a constant substitution rate of $2 \%$ per MYA (DeSalle et al., 1987), the Spanish HT supposedly diverged about 0.3 MYA. Genetic studies based on chloroplast DNA of Pinus sylvestris revealed a potential parallel evolution of the main host of $T$. piniperda. In $P$. sylvestris, haplotypes detected on the Iberian Peninsula were not found in other parts of Europe (Soranzo et al., 2000). The Pyrenean Range forms a gap in the geographic distribution of $P$. sylvestris between Northern Spain and Southern France (Fig. 1 - inset). According to Willis et al. (1998), no other pine species in that gap could have served as "bridge" species for $T$. piniperda.

The Chinese populations revealed four closely related HT. The average sequence divergence between European 
TABLE 1. Countries and abbreviations, locations, geographic coordinates and host trees from which T. piniperda and T. minor populations were collected. Accession numbers and collector's names are listed.

\begin{tabular}{|c|c|c|c|c|c|c|c|c|}
\hline Country & Location & $\mathrm{n}$ & lat. & long. & Host tree & Haplotype (HT) & Accession No. & Collected by \\
\hline \multicolumn{9}{|l|}{ T. piniperda } \\
\hline \multirow[t]{2}{*}{ Austria AUT } & Mattersburg & 4 & $47^{\circ} 45^{\prime} \mathrm{N}$ & $16^{\circ} 24^{\prime} \mathrm{E}$ & P. sylvestris & V, VII, IX & $\begin{array}{l}\text { AF367041 } \\
\text { AF367043 } \\
\text { AY239113 }\end{array}$ & $\begin{array}{c}\text { Gallego \& Galliàn, } \\
2001 \\
\text { B. Kohlmayr }\end{array}$ \\
\hline & Kaindorf & 1 & $47^{\circ} 22^{\prime} \mathrm{N}$ & $15^{\circ} 90^{\prime} \mathrm{E}$ & P. sylvestris & VI & AY239114 & authors \\
\hline \multirow[t]{2}{*}{ China CHN } & Jinlin & 6 & $43^{\circ} 53^{\prime} \mathrm{N}$ & $126^{\circ} 35^{\prime} \mathrm{E}$ & P. thunbergii & XXIV, XXV & $\begin{array}{l}\text { AY234048 } \\
\text { AY239112 }\end{array}$ & Chen Guofa \\
\hline & Liaoning & 4 & $41^{\circ} 00^{\prime} \mathrm{N}$ & $123^{\circ} 00^{\prime \prime} \mathrm{E}$ & P. tabliformis & $\begin{array}{l}\text { XXI, XXII, } \\
\text { XXIII, XXIV }\end{array}$ & $\begin{array}{l}\text { AY234046 } \\
\text { AY234047 } \\
\text { AY234048 } \\
\text { AY239111 }\end{array}$ & Chen Guofa \\
\hline Croatia HRV & Gaj & 4 & $45^{\circ} 29^{\prime} \mathrm{N}$ & $17^{\circ} 02^{\prime} \mathrm{E}$ & P. sylvestris & I, II & $\begin{array}{l}\text { AY234039 } \\
\text { AY234041 }\end{array}$ & B. Hrasovec \\
\hline Czech R. CZE & St. Boleslav & 5 & $50^{\circ} 12^{\prime} \mathrm{N}$ & $14^{\circ} 44^{\prime} \mathrm{E}$ & P. sylvestris & I, II & $\begin{array}{l}\text { AY234039 } \\
\text { AY234040 }\end{array}$ & M. Knizek \\
\hline Finland FIN & Joensuu & 3 & $62^{\circ} 36^{\prime} \mathrm{N}$ & $29^{\circ} 46^{\prime} \mathrm{E}$ & P. sylvestris & I, XII & $\begin{array}{l}\text { AY234039 } \\
\text { AY234044 }\end{array}$ & M. Robbo \\
\hline \multirow[t]{4}{*}{ France FRA } & Bordeaux & 3 & $44^{\circ} 50^{\prime} \mathrm{N}$ & $0^{\circ} 34^{\prime} \mathrm{W}$ & P. sylvestris & I, III, XI & $\begin{array}{l}\text { AY234039 } \\
\text { AY234042 } \\
\text { AY234043 }\end{array}$ & C. Kerdlhué \\
\hline & Mulhouse & 4 & $47^{\circ} 44^{\prime} \mathrm{N}$ & $7^{\circ} 21^{\prime} \mathrm{E}$ & P. sylvestris & I, VIII & $\begin{array}{l}\text { AY234039 } \\
\text { AY239115 }\end{array}$ & C. Kerdlhué \\
\hline & Quillant & 3 & $42^{\circ} 80^{\prime} \mathrm{N}$ & $2^{\circ} 15^{\prime} \mathrm{E}$ & P. sylvestris & XIII, XIV & $\begin{array}{l}\text { AY234050 } \\
\text { AY239109 }\end{array}$ & C. Kerdlhué \\
\hline & Pierronton & 2 & & & P. pinaster & VIII, XV & $\begin{array}{l}\text { AY239110 } \\
\text { AY239115 }\end{array}$ & C. Kerdlhué \\
\hline Italy ITA & P. Bocco & 4 & $44^{\circ} 30^{\prime} \mathrm{N}$ & $9^{\circ} 04^{\prime} \mathrm{E}$ & P. nigra & I, IV & $\begin{array}{l}\text { AY234039 } \\
\text { AY234040 }\end{array}$ & M. Faccoli \\
\hline Poland POL & Sekocin & 5 & $52^{\circ} 06^{\prime} \mathrm{N}$ & $20^{\circ} 52^{\prime} \mathrm{E}$ & P. sylvestris & I, II, XII & $\begin{array}{l}\text { AY234039 } \\
\text { AY234041 } \\
\text { AY234044 }\end{array}$ & J. Hilszczanski \\
\hline \multirow[t]{2}{*}{ Russia RUS } & Rybachii & 3 & $54^{\circ} 78^{\prime} \mathrm{N}$ & $20^{\circ} 51^{\prime} \mathrm{E}$ & P. sylvestris & IV, XX & $\begin{array}{l}\text { AY234040 } \\
\text { AY234049 }\end{array}$ & M. Mandelshtam \\
\hline & Yashchera & 5 & $59^{\circ} 94^{\prime} \mathrm{N}$ & $30^{\circ} 29^{\prime} \mathrm{E}$ & P. sylvestris & $\begin{array}{l}\text { I, XII, } \\
\text { XIII, XVI }\end{array}$ & $\begin{array}{l}\text { AY234039 } \\
\text { AY234044 } \\
\text { AY234045 } \\
\text { AY234050 }\end{array}$ & M. Mandelshtam \\
\hline Spain ESP & Teruel & 3 & $40^{\circ} 21^{\prime} \mathrm{N}$ & $1^{\circ} 06^{\prime} \mathrm{W}$ & P. pinaster & $\begin{array}{l}\text { XVII, XVIII, } \\
\text { XIX }\end{array}$ & $\begin{array}{l}\text { AF367047 } \\
\text { AF367048 } \\
\text { AF367049 }\end{array}$ & $\begin{array}{c}\text { Gallego \& Galliàn, } \\
2001\end{array}$ \\
\hline \multirow[t]{3}{*}{ Sweden SWE } & Uppsala & 3 & $59^{\circ} 52^{\prime} \mathrm{N}$ & $17^{\circ} 38^{\prime} \mathrm{E}$ & P. sylvestris & VII, X & $\begin{array}{l}\text { AF367041 } \\
\text { AF367046 }\end{array}$ & $\begin{array}{c}\text { Gallego \& Galliàn, } \\
2001\end{array}$ \\
\hline & Tormestorp & 3 & $56^{\circ} 07^{\prime} \mathrm{N}$ & $13^{\circ} 44^{\prime} \mathrm{E}$ & P. sylvestris & I & AY234039 & Schlyter \\
\hline & Lund & 2 & $55^{\circ} 42^{\prime} \mathrm{N}$ & $13^{\circ} 11^{\prime} \mathrm{E}$ & P. sylvestris & IV & AY234040 & Schlyter \\
\hline Switzerland CHE & Liesberg & 4 & $47^{\circ} 38^{\prime} \mathrm{N}$ & $7^{\circ} 42^{\prime} \mathrm{E}$ & P. sylvestris & I, XII & $\begin{array}{l}\text { AY234044 } \\
\text { AY234039 }\end{array}$ & M. Kenis \\
\hline USA & Snow Cap & 3 & $42^{\circ} 41^{\prime} \mathrm{N}$ & $84^{\circ} 30^{\prime} \mathrm{W}$ & P. sylvestris & I, IV & $\begin{array}{l}\text { AY234039 } \\
\text { AY234040 }\end{array}$ & B. Haack \\
\hline \multicolumn{9}{|l|}{ T. minor } \\
\hline Austria & Mattersburg & 2 & $47^{\circ} 45^{\prime} \mathrm{N}$ & $16^{\circ} 24^{\prime} \mathrm{E}$ & P. sylvestris & & U82583 & B. Kohlmayr \\
\hline China & Liaoning & 2 & $41^{\circ} 00^{\prime} \mathrm{N}$ & $123^{\circ} 00^{\prime \prime} \mathrm{E}$ & P. tabliformis & & AY237724 & Chen Guofa \\
\hline
\end{tabular}

and Chinese populations was $1.24 \%$. The closest relationship between the Chinese HT XXII and the Russian HT $\mathrm{XX}$ was $0.77 \%$. Little information exists about the genetic divergence of Asian and European populations in the subfamily Hylesininae. In the subfamily Ipinae, Ips cembrae collected from Asia and Europe showed a 4\% 

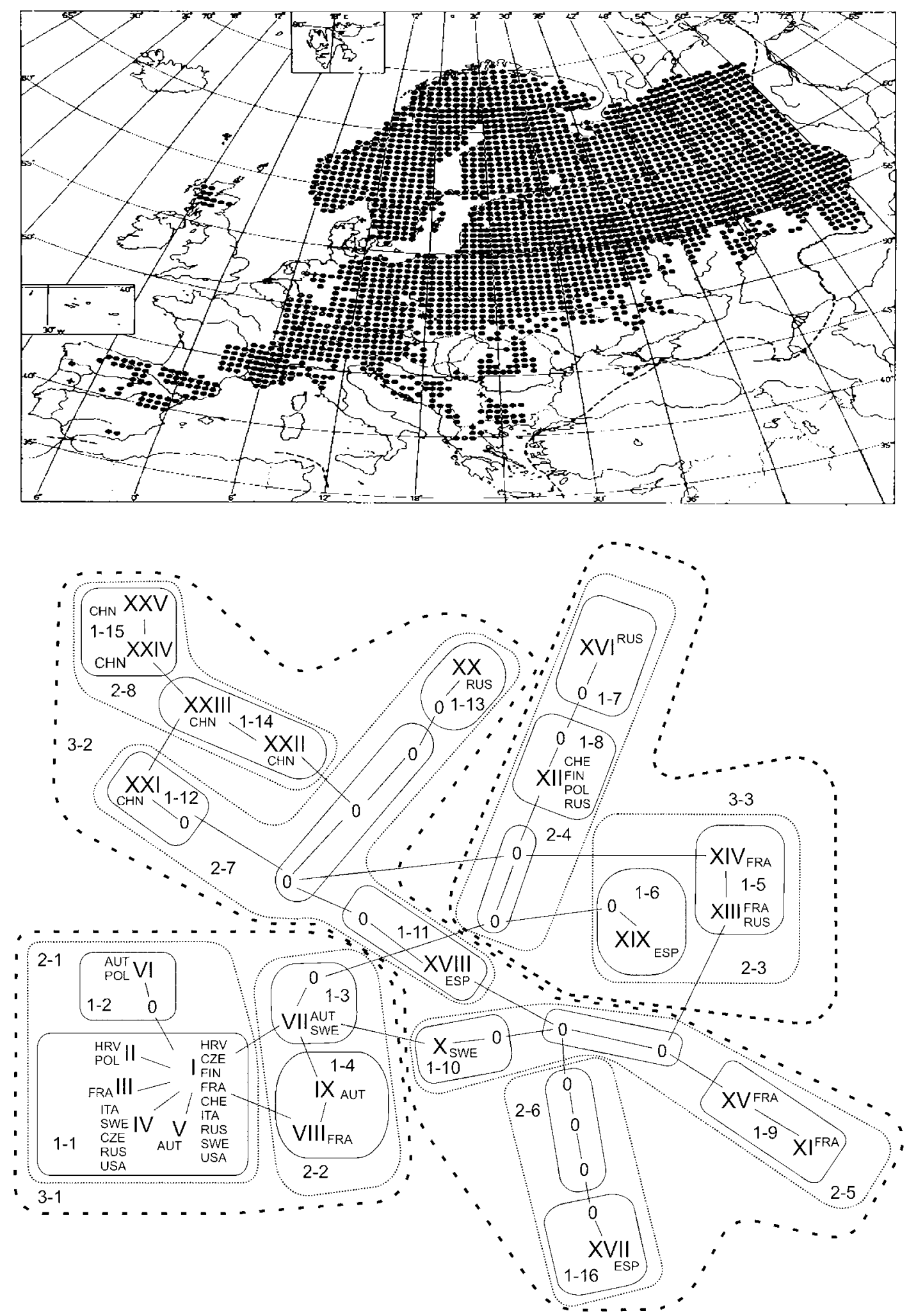

Fig. 1. Haplotype network based on mutational differences in the COI mtDNA sequences of pine shoot beetle T. piniperda populations. Haplotypes are presented as Roman numerals and each bar represents a mutational step, and " 0 " refers to missing or theoretical haplotypes. The origins of the haplotypes are listed in Table 1. Inset shows the current distribution of Pinus sylvestris in Europe (from Willis et al., 1998). For abbreviations of the countries see Table 1.

genetic divergence (Stauffer et al., 2001), whereas the genetic differentiation in Ips typographus from European and Asian populations was similar $(<1.5 \%)$ to the one found in T. piniperda (Stauffer, 2003). To obtain more information about the genetic structure of European and Asian Tomicus species, specimens of the closely related 
TABLE 2. Result from the nested geographic analysis. $D c$ is the clade distance and $D n$ is the nested clade distance, $I-T$ is the average difference between interior vs. tip clades for both distance measures (no $I-T$ value was computed when no interior or tip clade was present) (see Templeton (1988) for details). The superscript $S$ means that the measure was significantly small and $L$ that the distance was significantly large (both at the $5 \%$ level). Interior clades are shaded.

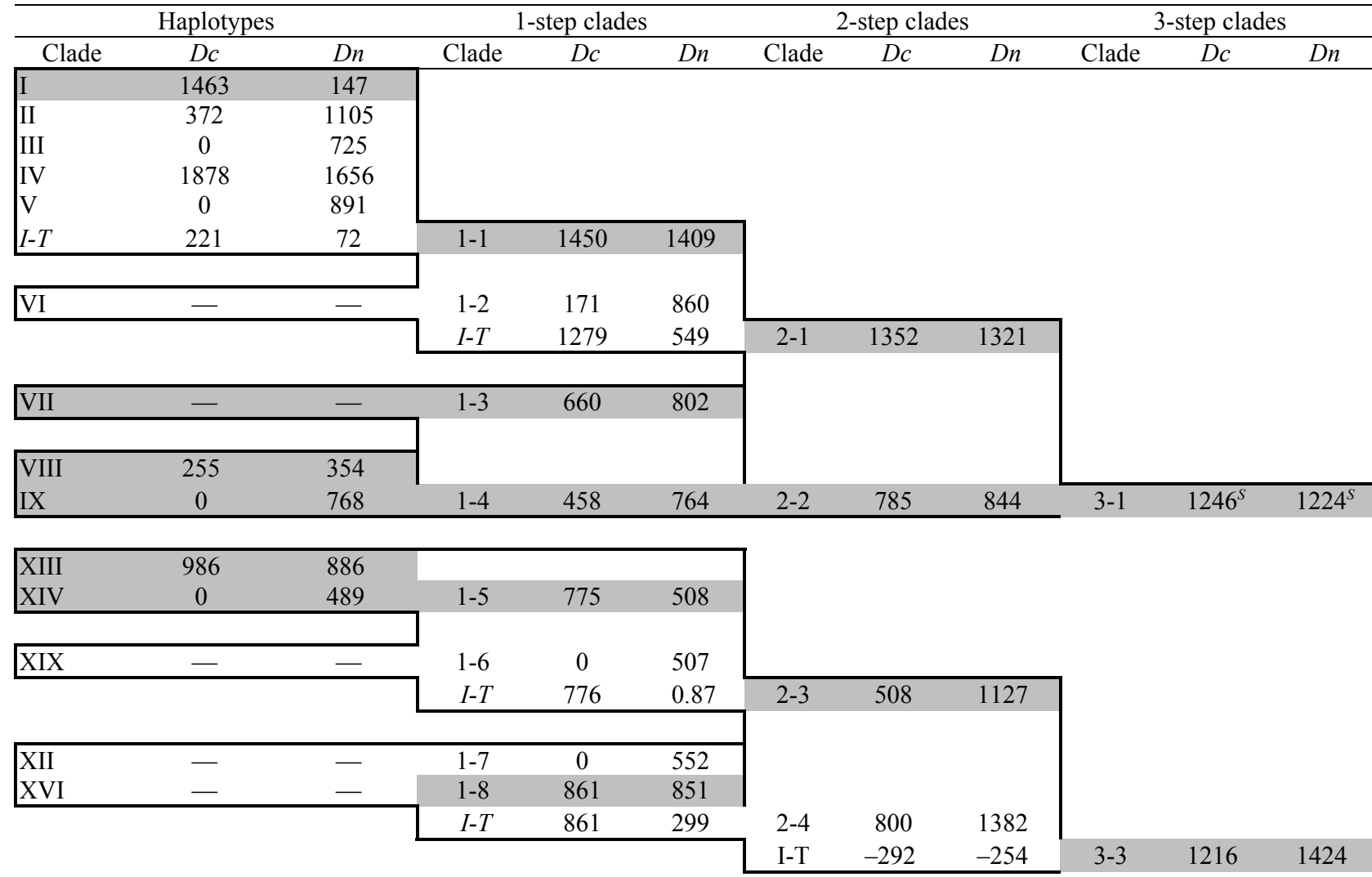

\begin{tabular}{|c|c|c|c|c|c|c|c|c|c|}
\hline $\mathrm{X}$ & - & - & $1-10$ & 0 & 1421 & & & & \\
\hline XI & 0 & 75 & & & & & & & \\
\hline XV & 0 & 50 & $1-9$ & 60 & 604 & & & & \\
\hline$I-T$ & 0 & -25 & $I-T$ & -60 & 817 & $2-5$ & 838 & $3252^{S}$ & \\
\hline XVII & - & - & $1-16$ & 0 & 0 & \multirow[t]{4}{*}{$2-6$} & \multirow[t]{4}{*}{0} & \multirow[t]{4}{*}{3823} & \\
\hline XVIII & - & - & $1-11$ & 0 & 2014 & & & & \\
\hline XX & - & - & $1-13$ & 0 & 1081 & & & & \\
\hline \multirow[t]{2}{*}{ XXI } & - & - & $1-12$ & 0 & 7552 & & & & \\
\hline & & & $I-T$ & 0 & 3702 & \multirow[t]{3}{*}{$2-7$} & \multirow[t]{3}{*}{2411} & \multirow[t]{3}{*}{3527} & \\
\hline XXII & - & - & & & & & & & \\
\hline XXIII & - & - & $1-14$ & 0 & 249 & & & & \\
\hline XXIV & 193 & 174 & \multirow{5}{*}{$\begin{array}{c}1-15 \\
I-T\end{array}$} & & & \multirow{5}{*}{$\begin{array}{l}2-8 \\
\mathrm{I}-\mathrm{T}\end{array}$} & \multirow{5}{*}{$\begin{array}{r}213^{S} \\
1545^{L}\end{array}$} & \multirow{5}{*}{$\begin{array}{r}6109^{L} \\
-2471^{S}\end{array}$} & \\
\hline XXV & 0 & 86 & & & & & & & \\
\hline$I-T$ & 192 & 87 & & 139 & $198^{S}$ & & & & \\
\hline & & & & -138 & 51 & & & & \\
\hline & & & & & & & & & $4298^{L}$ \\
\hline
\end{tabular}

T. minor were sequenced (Table 1). A divergence of $6.4 \%$ between the European and the Chinese populations was detected. Thus, the evolutionary histories of $T$. piniperda and T. minor in Europe and Asia are different. According to the molecular clock of arthropod species (DeSalle et al., 1987), the Asian T. minor diverged from the European populations about 3 MYA whereas the Asian $T$. piniperda diverged from the European populations about 0.6 MYA. Although these two species occur sympatrically it seems that their history is diverse.

Two HT of $T$. piniperda were found in North America that were identical to HT found in Europe. This indicates that Europe was the source of the American populations of $T$. piniperda. The beetle was found for the first time on 
the American continent in 1992 (Haack \& Kucera, 1993). In $2000, T$. piniperda was already present in 12 US states and in two provinces of Canada (Haack et al., 2000). Carter et al. (1996) suggested that the populations in the US were established separately in Illinois near Lake Michigan and in Ohio along Lake Erie, according to population analysis by RAPD. Knowing the exact origin(s) of North American T. piniperda populations could help in predicting important life history traits of this pest species, such as their hibernation behaviour and in using natural enemies as biocontrol agents (Metcalf \& Luckmann, 1994). More individuals and finer tuned markers, like the recently developed microsatellites (Kerdelhué et al., 2003), are needed for a clearer picture.

ACKNOWLEDGEMENTS. We like to thank Andrea Stradner for technical assistance, Gernot Hoch, Florian Steiner, Birgit Schlick-Steiner and two anonymous reviewers for critically reading earlier drafts of this paper and the colleagues listed in Table 1 for sending us numerous samples.

\section{REFERENCES}

Carter C.M., Robertson J.L., Haack R.A., Lawrence R.K. \& Hayes J.L. 1996: Genetic relatedness of North American populations of Tomicus piniperda (Coleoptera: Scolytidae). $J$. Econ. Entomol. 89: 1345-1353.

Clement M., Posada D. \& Crandall K.A. 2000: TCS: Computer program to estimate gene genealogies. Mol. Ecol. 9: 1657-1659.

Cognato A., Seybold S.J., Sperling F.A.H. 1999: Incomplete barriers to mitochondrial gene flow between pheromone races of the North American pine engraver, Ips pini (Say) (Col.: Scolytidae). Proc. Roy. Soc., Lond. B 266: 1843-1850.

CRANDAll K.A. 1996: Multiple interspecies transmissions of human and simian T-cell leukemia/lymphoma virus type I sequences. Mol. Biol. Evol. 13: 115-131.

DeSalle R., Freedman T., Prager E.M. \& Wilson A.C. 1987: Tempo and mode of sequence evolution in mitochondrial DNA of Hawaiian Drosophila. J. Mol. Evol. 26: 157-164.

Gallego D. \& Galí́n J. 2001: The internal transcribed spacers (ITS1 and ITS2) of the rDNA differentiate the bark beetle forest pests Tomicus destruens and T. piniperda. Insect Mol. Biol. 10: 415-420.

HAACK R.A. \& KucErA D. 1993: New Introduction - Common Pine Shoot Beetle, Tomicus piniperda (L.). USDA Forest Service, North-Eastern Area, Pest Alert NA-TP-05-93.

Haack R.A., Poland T.M., Petrice T.R. \& Gennrich M.A. 2000: Range expansion of Tomicus piniperda since 1992 and notes on other new exotics. Newsletter Michigan Entomol. Soc. 45: 9-10.

Huntley B. \& Birks H.J.B. 1983: An Atlas of Past and Present Pollen Maps for Europe: 0-13000 Years ago. Cambridge University Press, Cambridge, 657 pp.

Kerdelhué C., Roux-Morabito G., Forichon J., Chambon J.M., Robert A. \& Lieutier F. 2002: Population genetic structure of Tomicus piniperda L. (Curculionidae, Scolytinae) of different pine species and validation of Tomicus destruens (Woll.). Mol. Ecol. 11: 483-494.

Kerdelhué C., Mondor-Genson G., Rasplus J.Y., Robert A. \& LiEUTIER F. 2003: Characterization of five microsatellite loci in the pine shoot beetle Tomicus piniperda L. (Coleoptera: Scolytidae). Mol. Ecol. Notes 3: 100-101.
Kelley S.T., Farrell B.D. \& Mitton J.B. 2000: Effects of specialization on genetic differentiation in sister species of bark beetles. Heredity 84: 218-227.

Kohlmayr B., Riegler M., Wegensteiner R. \& Stauffer C. 2002: Morphological and genetic identification of the three pine pests of the genus Tomicus (Coleoptera: Scolytidae) in Europe. Agric. Forest Entomol. 4: 151-157.

LÅngström B., Lisha L., Hongpin L., Peng C., Haoran L., Hellqvist C. \& Lieutier F. 2002: Shoot feeding ecology of Tomicus piniperda and Tomicus minor in southern China. $J$. Appl. Entomol. 126: 333-342.

Metcalf R.L. \& Luckmann W.H. 1994: Introduction to Insect Pest Management. Wiley, New York, 247 pp.

PfeFfer A. 1994: Zentral- und westpaläarktische Borken- und Kernkäfer (Coleoptera: Scolytidae, Platypodidae). Pro Entomologia, c/o Naturhistorisches Museum Basel.

Posada D. \& CRANDAll K.A. 2001: Intraspecific gene genealogies: trees grafting into networks. TREE 16: 37-45.

Posada D., Crandall K.A. \& Templeton A.R. 2000: GeoDis: A program for the Cladistic Nested Analysis of the Geograpical Distribution of Genetic Haplotypes. Mol. Ecol. 9: 487-488.

Postner M. 1974: Scolytidae (= Ipidae), Borkenkäfer. In: Schwenke W. (ed.): Die Forstschädlinge Europas. Band 2. Parey Verlag, Berlin, pp. 334-482.

SchedL K.E. 1932: Scolytidae, Platypodidae. In: Winkler A. (ed): Catalogus Coleopterorum Regionis Palaearctica. Eigenverlag, Wien, pp. 1632-1642.

Simon C., Frati F., Beckenbach A., Crespi B., Liu H. \& Flook P. 1994: Evolution, weighting and phylogenetic utility of mitochondrial gene sequences and a compilation of conserved polymerase chain reaction primers. Ann. Entomol. Soc. Am. 87: 651-701

Solheim H., LÅngStröm B. \& Hellqvist C. 1993: Pathogenicity of the blue-stain fungi Leptographium wingfieldii and Ophiostoma minus to Scots pine: effect of tree pruning and inoculum density. Can. J. For. Res. 23: 1438-1443.

Soranzo N., Alia R., Provan J. \& Powell W. 2000: Patterns of variation at mitochondrial sequence-tagged-site provides new insights into the postglacial history of European Pinus sylvestris populations. Mol. Ecol. 9: 1205-1211.

STAUFFER C. 2004: Genetic tools in scolytid research. In: Lieutier F. (ed.): European Bark and Wood Boring Insects in Living Trees: A Synthesis. Kluwer. (in press)

Stauffer C., Lakatos F. \& Hewitt G. 1999: Phylogeography and postglacial colonization routes of Ips typographus (Coleoptera: Scolytidae). Mol. Ecol. 8: 763-773.

Stauffer C., Kirisits T., Nussbaumer C., Pavlin R. \& WingFIELD M.J. 2001: Phylogenetic relationships between European and Asian eight spined larch bark beetle populations (Coleoptera, Scolytidae) inferred from DNA sequences and fungal associates. Eur. J. Entomol. 98: 99-105.

SwofFord D.L. 1998: PAUP*: Phylogenetic Analysis Using Parsimony (*and other methods). Version 4.0b3. Sinauer, Sunderland, Mass.

Templeton A.R. 1998: Nested clade analysis of phylogeographic data and testing hypotheses about gene flow and population history. Mol. Ecol. 7: 381-397.

Templeton A.R. \& Sing C.F. 1993: A cladistic analysis of phenotypic associations with haplotypes inferred from restriction endonuclease mapping. IV. Nested analysis with cladogram uncertainty and recombination. Genetics 134: 659-669.

Templeton A.R., Routman E. \& Phillips C.A. 1995: Separation the population structure from population history: A cladistic analysis of geographical distribution of mtDNA haplotypes in the tiger salamander. Genetics 140: 767-782. 
Templeton A.R., Crandall K.A. \& Sing C.F. 1992: A cladistic analysis of phenotypic associations with haplotypes inferred from restriction endonuclease mapping and DNA sequence data. III. Cladogram estimation. Genetics 132: 619-633.

Templeton A.R., Boerwinkel E. \& Sing C.F. 1987: A cladistic analysis of phenotypic associations with haplotypes inferred from restriction endonuclease mapping. I. Basic theory and an analysis of alcohol dehydrogenase activity in Drosophila. Genetics 117: 343-351.

Thompson J.D., Higgins D.G. \& GibBson T.J. 1997: Clustal W: improving the sensitivity of progressive multiple sequence alignment through sequence weighting, position specific gap penalties and weight matrix choice. Nucl. Acid Res. 22: 4673.

WiLlis K.J., BennetT K.D. \& BiRKs H.J. 1998: The late Quaternary dynamics of pines in Europe. In: Richardson D.M. (ed.): Ecology and Biogeography of Pinus spp. Cambridge University Press, Cambridge, pp.107-121.

Wood S. \& BRight D.E. 1992: A Catalog of Scolytidae and Platypodidae (Coleoptera), Part 2: Taxonomic Index Vol. A. Great Basin Naturalist Memoirs, No. 13, Brigham Young University, $1553 \mathrm{pp}$.

Received September 22, 2003; revised November 20, 2003; accepted January 14, 2004 